\title{
On Augmenting Growth, Photosynthesis, Enzymatic Activities and Nutrient Contents of Brassica juncea (L.) by the Application of Plant Growth Regulators ${ }^{\dagger}$
}

\author{
Shaistul Islam (D) and Firoz Mohammad *(D) \\ Plant Physiology and Biochemistry Section, Department of Botany, Faculty of Life Sciences, \\ Aligarh Muslim University, Aligarh 202002, India; shahidbhat78303@gmail.com \\ * Correspondence: Firoz_59@rediffmail.com \\ + Presented at the 1st International Electronic Conference on Plant Science, 1-15 December 2020; \\ Available online: https:/ /iecps2020.sciforum.net/.
}

check for updates

Citation: Islam, S.; Mohammad, F. On Augmenting Growth,

Photosynthesis, Enzymatic Activities and Nutrient Contents of Brassica juncea (L.) by the Application of Plant Growth Regulators. Biol. Life Sci. Forum 2021, 4, 3. https://doi.org/ 10.3390/IECPS2020-08652

Published: 1 Decemer 2020

Publisher's Note: MDPI stays neutral with regard to jurisdictional claims in published maps and institutional affiliations.

\section{Copyright: (C) 2020 by the authors.} Licensee MDPI, Basel, Switzerland. This article is an open access article distributed under the terms and conditions of the Creative Commons Attribution (CC BY) license (https:// creativecommons.org/licenses/by/ $4.0 /)$.
Abstract: In a simple randomized pot experiment, the effect of nine plant growth regulators (PGRs), namely benzyl amino purine, chlormequat, gibberellic acid, indole acetic acid, indole butyric acid, kinetin, methyl jasmonate, salicylic acid, and triacontanol was studied on growth and physiobiochemical performance of mustard (Brassica juncea L.)Plants were sprayed with a uniform concentration of PGRs each at $5 \mu \mathrm{M}$ twice at 50 and 70 days after sowing (DAS). At 80 DAS, various parameters were studied. The data showed varied effects of PGRs on the various studied parameters. Among the PGRs, salicylic acid proved best for most of the parameters; for example, it increased root length by $35.92 \%$, shoot length by $26.56 \%$, root fresh mass by $33.15 \%$, shoot dry mass by $31.86 \%$, root dry mass by $37.09 \%$, area per leaf $27.05 \%$, chlorophyll content by $29.04 \%$, photosynthetic rate by $29.91 \%$ and carbonic anhydrase activity by $28.82 \%$. Gibberellic acid surpassed others for leaf relative water content, leaf phosphorous and potassium content. Moreover, triacontanol gave the maximum value for nitrate reductase activity and leaf nitrogen content. The data revealed the overall superiority of salicylic acid for improving the growth and physio-biochemical performance of mustard.

Keywords: Brassica juncea (L.); plant growth regulators; photosynthesis and related parameters; enzymatic activities; nutrient content

Supplementary Materials: The following are available online at https:/ /www.mdpi.com/article/10 .3390/IECPS2020-08652/s1.

Institutional Review Board Statement: Not applicable.

Informed Consent Statement: Not applicable.

Data Availability Statement: Not available. 